\title{
9
}

\section{Juvenile (In)Justice in Darwin: Young People's Voices from the Don Dale Youth Detention Centre}

\author{
Pippa Rudd, Kate Senior and Jared Sharp
}

\section{Introduction}

The face of youth crime, until yesterday, was the one we could see. Break ins, stolen cars, wanabee teen gangsters. And seemingly endless re-offending. There has been an undeniable frustration within the community that our justice system does not break the cycle and that kids leave youth detention to resume lives of near poverty, drug use and petty crime. Where the community can be forgiven, and the NT Government cannot is that treatment of our troubled youth had a face that most of us could not see. There can be no doubt, after viewing the footage on Four Corners, that the brutalisation of young people within Don Dale is an overwhelming cause of that reoffending. (Smee 2016)

So ran the front page of the NT News on 26 July 2016. Despite several formal enquiries and a series of damning reports by Amnesty International into the Don Dale Youth Detention Centre, it was the Australian Broadcasting Corporation's (ABC's) investigative news program Four Corners' episode 'Australia's Shame', broadcast on 25 July 2016, that finally exposed the brutality of youth detention in Darwin. The conditions in which detainees were placed and the punishments inflicted upon them 
demanded an urgent response (Amnesty International 2014; Bath and Gwynne 2015; Vita 2015). That response was the creation of the Royal Commission into the Detention and Protection of Children in the Northern Territory. ${ }^{1}$ Established in 2016, the royal commission released its report in 2017; it described the 'systemic and shocking failures' of the youth detention system, including the failure to comply with basic human rights (Commonwealth of Australia 2017).

This chapter is based on the perspectives of three Aboriginal youths who were incarcerated in the Don Dale facility three years prior to the ABC's exposé. ${ }^{2}$ It offers an anthropological perspective on the causes of persistent delinquency and/or incarceration of Aboriginal young people in the Northern Territory. Insofar as it describes firsthand experiences of pathways into and out of youth detention, it contributes a facet of understanding that supports efforts at effective reform. ${ }^{3}$ One of the royal commission's recommendations was to implement policies to incorporate Aboriginal cultural competence and safety in the design and delivery of education programs, activities and services for children and young people in detention' (Royal Commission into Protection and Detention of Children in the Northern Territory 2017, 468). As this chapter demonstrates, identifying and understanding the 'cultural' context in which young Aboriginal people begin, and too often continue, what may be a lifelong engagement with Australia's detention system, is vital for policy development and implementation. Non-Aboriginal service providers, we suggest, need more than a general understanding of what is labelled 'culture' by some Aboriginal people as well as non-Indigenous outsiders. This chapter demonstrates how a more complex anthropological view of 'culture'-one that incorporates

1 The royal commission found that:

Many of the children who come into contact with the youth justice and child protection systems do so as a result of the underlying drivers of socioeconomic inequality including racism, remoteness, poverty, housing issues, poor physical and mental health and disabilities. This includes cognitive impairments such as fetal alcohol spectrum disorder, as well as trauma and intergenerational trauma. This forms the backdrop for many of the children and young people who get caught up in the youth justice and child protection systems in the Northern Territory and is a fundamental challenge which must be acknowledged and addressed. (Commonwealth of Australia 2017, 40).

While the recognition of such factors is an important step in addressing the problems associated with youth delinquency, we suggest that this needs to be complemented with greater understanding of how such factors work out in the lives of specific individuals.

2 Ethical clearance for this project was granted by the Menzies School of Health Research Human Ethics Committee (Ref: 2013-2093).

3 The commission's activity included interviews with adults and young people. These interviews focused primarily on experiences of family separation and detention in the Don Dale facility. 
an account of the 'intercultural' and associated experiences of living within an admixture of two, often contradictory, cultural systems-expands understanding of the context of Aboriginal offenders' lives and thus, ideally, encourages and enables more appropriate treatment of both delinquent and Aboriginal youth more generally (Anthony 2013; Blagg and Anthony 2019; Blagg, Tulich and Bush 2017; White and Cunneen 2015). ${ }^{4}$

\section{Stories from Inside}

The interviews for these stories were conducted by Pippa Rudd, then a $\mathrm{PhD}$ student. Her work involved intensive observation at the Darwin Youth Justice Court as well as interviews with incarcerated young people in the Don Dale Youth Detention Centre. The interviews took place in May 2014, which can be seen as a midpoint in the timeline of incidents at the detention centre (see Appendix: Timeline). Tragically, Pippa lost her battle with cancer before she was able to complete her work. This chapter has been compiled through analysis of her transcribed interviews as well as un-transcribed audio material, with constant reference to her meticulous field notes. The following presents a selection of her interviews. Some of the speakers were interviewed on multiple occasions. The audio recordings are punctuated by the sounds of heavy doors banging and keys rattling. All the young people interviewed were 17 years old and worried about being transferred to the adult prison. Most had been in Don Dale several times before, and so described it as being 'normal' or 'alright'. This was despite the fact that all had experienced, or were currently experiencing, periods of being a 'red-shirter' (high security), which meant being denied the luxury of a fan or air-conditioning in Darwin's heat. ${ }^{5}$

\section{Carmen's Story}

Carmen's interviews are tough and feisty. An articulate young woman, she evidently enjoyed her interaction with Pippa. In April 2014, Carmen was worried about being transferred to the adult prison, as she would turn

4 Sociologists have also contributed important studies on these issues (see e.g. Blagg and Anthony 2019).

5 The young people were differentiated by the colour of their shirts. The most problematic young people wore red shirts and were denied privileges such as having a fan. This was supposed to be an incentive for them to change their behaviour. 
18 the following August. First arrested at 14, she was a frequent detainee at Don Dale. Her arrests all appear to be due to fighting. She spoke about being bullied at school and learning how to fight to defend herself, behaviour that led to her incarceration:

My first time was 'cos I had a fight. I had got used to fighting from being bullied at school and started defending myself. And I guess, just went overboard, you know, out of control. I thought I could give that person a hiding, teach that person a lesson. 'Cos I was the one that used to get bullied. And didn't tolerate that stuff.

She talked about the ongoing burden of being continually monitored by the police and being a focus of their attention because of her Indigenous status:

Oh my God, that's annoying, they harass me all the time. I can't even go into the shopping centres, do my own stuff without them walking up to me and saying: 'what are you doing here, don't you have trespassing orders against the place?' And umm, I'll be like 'no, that's not me, you got the wrong person there'. Then they'll harass me, they'll be like 'don't be going stealing, we'll be watching you on camera. Otherwise you can just leave this space right now'. And I'll be like 'what are youse on about, I come here to do shopping, not come here to harass people or annoy people or start fights and anything. Or steal'. And they'll be like 'sure, we know what you're like'.

Carmen described life under constant surveillance as being 'too stressful'. This, combined with an unchanged home environment and pressures from family, provides insight into the serial recidivism of some in Don Dale:

But the only reason I breached this time is like family business, a little bit of fighting and that. It just pisses me off. It's like every time I come out, I'm involved with shit that I don't want to be involved with. And I try to tell people oh umm, I'm out to do other stuff, not to be involved with fights and shit, because other people bring my name up. And that's when I get pissed off, I get stressed out. And yeah, that's when I'll be like, fuck it, I'm too used to being in Don Dale, I'm going back there. 
The conditions of bail, which include a curfew and non-association orders, could also be difficult to comply with. Carmen talked about being 'set up to fail'. For example, her mother was homeless and so she was sent to live with other relatives. She could exert little control over these members of her family and was pulled back into criminal behaviours.

Carmen described a family life in which parents engaged in violent behaviour directed at each other and their children. Her father attacked both her and her brother, using extreme physical violence:
C: Family fights from mother and father and smash it out, I grew up with that stuff, like domestic violence and my own brother went to welfare because of my dad. We don't get along with him, he pushed my brother out of the car, in Darwin he used to bash me and my brother around. That's when my mum got sick of it. She had to run away with us. She took off after she had her last kid with him. When I was three and that's when Jessie was born.
P. That's a brave thing to do.
C. He was over controlling for her. He was a druggie, alcoholic. At least my mum did that, because if she was still with him today, I'd probably be worse than I am now.

Despite this family history, longing and concern for her family are pervasive in Carmen's discourse. She speaks of wanting to shield her brothers and sisters from her situation and to prevent them from following her path:

C: I ask my little sisters, 'You mob going to stay in school now?' 'Yes we gonna stay in school 'cos we know what will happen if we hang around with the wrong crew and we do the wrong stuff and we gonna get locked up if we break the law'.

P: Do they come and visit?

C: Nah, I don't want them to come and visit.

P: You don't want them to do that? Why is that?

C: If my family come and see me, especially those three, I just get upset and just start thinking of them and start stressing out and I get angry and take it all out on me 'cos of what I've done. And yeah, my little sisters and my baby brother shouldn't be coming in here and seeing me, in the wrong place. They should be seeing me on the outside. 
Carmen's account of the factors leading up to one of the incidents at Don Dale, in which a group of young people climbed into the roof of the centre (see Appendix: Timeline), highlights the everyday humiliation and deprivations that young people were subjected to within the centre:

One night the boss came back and he was being a smart arse and he was like: 'If youse mob wanna keep acting like animals', which we wasn't. We was just sitting there, thinking 'what the fuck are you on about?' And he was like, 'We'll start treating you like animals in pounds then'. And we got pissed off, it was like: 'What the fuck? Why would you say that to us?' So, it was like, if you want to treat us like animals, we will show you what animals are like. So that's what we did, we broke into the roof and smashed it up. But ah well, that was his fault for starting it all. They didn't feed the boys properly last night, they didn't give them much feed, most of the boys. They left them to starve on purpose. And, umm yeah we made a plan and got up in the roof.

Carmen's overall discourse may be read as one of resilience. She has given up smoking and drinking and talks about transforming her desire to fight into a formal martial art. Rationalising her experience makes Don Dale bearable:

I guess this place is just like a little holiday camp. Makes you think of everything in here, going forwards, what you should have done, shouldn't have done. Should have stuck to this thing, should have done that thing.

\section{Joel's Story}

Joel is also on the brink of turning 18. When he is not in Don Dale, he lives with his grandmother and two brothers. Another brother is in the adult prison, Darwin Correctional Centre, for the same crime as Joel: a ram raid. The severity of his crimes has increased since he first faced court at 13 for stealing a bike. Since then, he has been to court 'so many times that I have lost count'. His first time in Don Dale was in 2013, and since then he has been frequently in and out of detention:

Then I just be coming back after that, ever since, come in for a week get out, come in for three days get out ... just back and forth ... Once you've actually served time here, they know you've seen what it's like on the inside and they know, it's your choice, you know what it's like and we're going to keep sending you back. So they send you back. 
According to him, the courts think that no one would willingly put themselves in a position in which they would be returned to Don Dale once they had spent time there. Assuming his interpretation of the justice system is accurate, it highlights the court's ignorance of factors affecting an individual's ability to choose to stay out of trouble. As Joel says, 'it just happens, you get in trouble':

But it's not like that, you don't, you don't want to come back. No one wants to come back. It just happens, you get in trouble. You make mistakes, everyone makes mistakes. My biggest mistake is drinking.

Joel talked about struggling through school with undiagnosed dyslexia and eventually giving up because it was all too difficult:

Nah, I started wagging and I'd just start walking out of classes when I'd get to something too hard, too embarrassed to ask for help or anything, I'd just stand up and walk off. Yeah, that's that.

Like Carmen, Joel experienced the revolving door of Don Dale because of his inability to comply with bail restrictions. He said that he would agree to all the restrictions 'but would know in the back of my head that I'm not going to go by those'. Going back to Don Dale was seen as inevitable in the pattern of his everyday life and he characterised it in the same way as smoking weed or drinking - it was too difficult to change when everyone else was doing the same thing:

It's just like, like I'll get drunk one day and my mates will be around my house ... they'll all leave and I'll be like 'fuck it, I'll just come with youse'.

Alcohol was the main undermining factor in his life:

Everything I do is when I'm drunk. I don't go out stealing sober, I don't even, can't even, steal socks from Kmart when I'm sober. I don't, I'm not, I don't steal. When I'm drunk, I go steal stuff, just sort of motivates me. To me, it's having fun.

He spoke of his ability to drink a whole carton (24 cans) to get 'drunk, really drunk' and said that he had been a heavy drinker since the age of 12 . Yet, what appears to have been a very cursory assessment of Joel by a drug and alcohol counsellor failed to effectively explore his relationship with alcohol. According to Joel, the person running the sessions commented: 'We don't target people like you for this session. You don't smoke weed, 
you don't smoke drugs, you drink on occasion.' Joel says that his life of drinking, stealing, selling drugs and ending up in Don Dale are just part of being young. In his words, he was 'getting it all out of his system' before he turned 18 and had to face the frightening and unknown circumstances of adult prison.

\section{Samuel's Story}

Samuel's childhood was spent in foster homes. His brothers and sisters are also in foster homes, but in a different state, and he has very little knowledge about their whereabouts or wellbeing. Samuel was ambivalent about being in Don Dale; he had run away from every foster care placement because he didn't like being sent to live with strangers. At the time of his detention, his father was serving a seven-year jail sentence in Queensland and Samuel's girlfriend was also in Don Dale. Being at Don Dale was one of the most consistent experiences in his teenage years, providing him, it seems, with sense of stability in his life. This is indicated in his discussion about being in court:

When I sit up there, I don't even listen. I just sit there and hope for the best. I know that I've been a bad lot, last time I was here I didn't want to get out, because I thought that this was the best place to be.

At that point in time, being incarcerated in Don Dale was the best option his limited circumstances had to offer.

However, when he was interviewed by Pippa, Samuel appeared to be highly anxious about his incarceration. He was wearing a 'red shirt' (indicating he was a high security risk) because he had tried to escape at every opportunity. His father had just been released from prison, as had his girlfriend, but because of their criminal records, neither were permitted to visit him. A desire to see people he cared about may well have motivated his escape attempts:

I don't want to be here. I've been here a month and a week now and realise this ain't what I want. My dad's been out for the first time in my life. I was real depressed and stuff and then my girlfriend got out the next days and I tried calling her last night and stuff and no answer. Tried calling my grandma to talk to my dad, no answer. Ahh so stressing out. 
Samuel talked about his ambitions to reconnect with a father he had not seen for seven years and, while he acknowledged feeling anxious about this meeting, he also had high expectations for a good life with his father, an opportunity, perhaps, to reclaim some of his lost childhood:

It's a little bit scary, I haven't seen him for seven years, I wouldn't even know if I would walk down the street and see him, I'd walk past like he was a normal person.

My dad will be there 24/7 and if I wanna go anywhere he can take me with him, because I'll be allowed out with him, to play football and stuff.

\section{Sociocultural and Psychological Factors Associated with Youth Incarceration}

Carmen, Joel and Samuel came from homes that were deeply dysfunctional in which they experienced few stable adult influences. Both Samuel and Joel regarded their grandmothers as the most important people in their lives, but also recognised that their grandmothers had little ability to control them or their peers. Drug use and alcohol were ubiquitous and deeply embedded in their criminal histories and exposure to violence (Rudd 2015). All three talked about violent episodes they had witnessed or experienced during their childhoods. Child and youth policy in the Northern Territory, with its narrow focus on the early determinants of child health, regarded these young people as broken beyond repair (Nossar 2014). From this perspective, investments in rehabilitation for youth are a waste of scarce resources. According to this viewpoint, the course and outcomes of these young people's lives were set in motion well before birth, with the effects of parental stress, drug and alcohol abuse affecting the developing infant (Allen 2011; Spencer 2003). Early exposure to violence is often considered to be associated with the development of violent behaviours in youth and adults, in a so-called 'cycle of violence' (Dodge, Bates and Pettit 1990; Lisak and Beszterczey 2007). This belief makes it easy to anticipate the transition from abused and neglected infant to youth drug dealer, teenage mother or violent criminal. But, as Bourgois (2003) has pointed out, this expectation does not encourage attention to the social, cultural and psychological factors shaping these young people, including their experiences of poverty within an increasingly affluent city, and the fact that they have no middle-class parent to dismiss their often 
petty crimes as 'youthful mischief' and keep them out of jail. The young people's stories are filled with accounts of constant monitoring and surveillance. This is in keeping with Tuari's (2013) argument about racist profiling by the police arising from an ongoing neo-colonial culture that is responsible, at least in part, for driving high rates of reoffending.

Rather than being seen as the passive victims of external factors, Bourgois (2003, 143) recommends seeing the deviant behaviour of marginalised young people as a deliberate response to their situation, though, tragically, one that can have very painful consequences for the individual and the community:

People ... have not passively accepted their structural victimisation. On the contrary, by embroiling themselves in the underground economy and proudly embracing street culture, they are seeking an alternative to their social marginalisation. In the process, on a daily level, they become the actual agents administering their own and their community's suffering.

At various points in their stories, the young people express ambivalence about their experiences in Don Dale; they have become accustomed to its conditions, despite their awareness of its deprivations and punishment. For Samuel, it was preferable to being placed in foster homes with strangers, a practice highlighted in the royal commission as being an important contributing factor in youth delinquency and crime (Commonwealth of Australia 2017).

Carmen and Joel said that life was easier inside than outside. The food, if not good, was at least regular and the young people were surrounded by their friends, in contrast to strangers in the foster home situation. Howerton et al. (2009) found that such perceptions were common in serial short-term prisoners, who had 'nothing at stake in the community' and the possibility of a more stable and predictable life inside.

All three young people were deeply fatalistic about meeting the conditions placed on them for non-custodial sentences and talked about agreeing to conditions that they had no hope or inclination to meet. All three were aware that the pressures inherent in their home and community lives would inevitably lead them to reoffend. Such conditions were often placed on them with scant regard for their circumstances. Samuel's contact with those with whom he perpetrated crimes was restricted by a 'non-association' condition. This prohibited personal contact with 
his brother, but they lived in the same house! The concept of choicechoosing not to do things that will lead them to detention-permeates their discourse, either in terms of their own resolve to do things differently or to demonstrate they have heard what people in authority have said to them. Despite considerable resolve, it is clear that the same pressures that undermined their ability to comply with parole conditions also undermined their ability to stay out of adult prison. For example, Joel gave up smoking drugs despite the fact that his whole family smoked around him. This is not an environment in which he can be expected to stay drug free.

\section{Conclusion}

In spite of the circumstances in which these three youths live, circumstances that readers might have trouble imagining, there is considerable resilience within their stories: each have made difficult choices and have managed to stick with them. But, as they teeter on the brink of an adult sentence, they remain buffeted by factors we fear may affect their resolve. Their lives are characterised by absent parents, unstable households, violence, homelessness, disconnection from education, and drug and alcohol abuse. They experience racially motivated monitoring and surveillance, making it difficult for them to be inconspicuous and stay out of trouble.

Their lives inside, although they sometimes appear to be less chaotic than their lives outside, are also violent, degrading and often deeply humiliating. They have lost contact or damaged their relationships with family members who are most dear to them, and they have lost chunks of their childhood, most poignantly expressed by Joel, who just wanted a dad to play footy with him.

Their stories of the sentencing process are permeated by fatalism and a sense that things are beyond their control—that things 'just happen'. The larger society's insistence on an agentic posture of making good choices stands in marked contrast to this lack of control. This strikes us as somewhat contradictory, especially given a policy environment heavily influenced by the notion of pre-determination with regard to delinquency. These young people appear to think that they have to make good choices to stay out of prison. The authorities reinforce this notion by asserting that they are in prison by choice: after all, who would want to go there? The reality we find in these young prisoners' texts is that choice is both 
extremely limited and difficult for this group whose experience to date has been one of repeated failure and who live in circumstances of deprivation and deep uncertainty.

Although the Four Corners report and the subsequent royal commission brought the conditions at Don Dale to national attention, there had been several previous reviews of the Don Dale facility and youth justice conducted in the Northern Territory.

In September 2014, Children's Commissioner Howard Bath launched an Own Initiative Investigation (allowed under the Children's Commission Act 2013) into the conditions at Don Dale. This was in response to an incident in which young inmates had armed themselves with homemade weapons and tried to escape, and guards had used CS gas (tear gas) and a prison security dog from the Darwin Correctional Centre (Bath and Gwynne 2015). This incident was also described in an Amnesty International report on 2 September 2014.

The Children's Commissioner's Report, completed by Commissioner Colleen Gwynne, was provided to the government in June 2015 and publicly released in September 2015 (Bath and Gwynne 2015). The report found major failings in the treatment of young people and breaches of the Youth Justice Act including:

- the use of prolonged solitary confinement of young people (up to 17 days), even though the legislative maximum allowance is 72 hours

- the housing of young people in solitary confinement cells that are unsanitary; do not have fans or air conditioners; do not have windows, natural light or ventilation; and do not have access to running water, in temperatures that can exceed $35^{\circ} \mathrm{C}$

- the failure to provide young detainees with access to education or rehabilitation programs

- the use of spit hoods, even in circumstances in which young people have no history of spitting

- the use of handcuffs and foot restraints

- the housing of young people in adult prisons

- the use of dogs and chemical agents, to the extent that one young person was exposed to tear gas for a period of eight minutes 
- a lack of policies and procedures to govern the use of force and restraints on young people

- the use of insufficiently trained staff to guard the youth detention centre

- a lack of accountability when excessive force is used.

One of the youth justice officers interviewed for the report did not blame the kids for 'going off' - he said that he would have done the same thing if he had been treated like they had and was 'surprised it didn't happen sooner' (Bath and Gywnne 2015). ${ }^{6}$

We may be surprised that, in 2016, it was clear that a royal commission was required, indicating not only an inability, or disinclination, to rectify the situation in which highly vulnerable youths were being placed, but also the complexity of the problem. These incidents provide the context and background for the stories of Carmen, Joel and Samuel.

6 The review was conducted by Michael Vita, who was the superintendent of the Reiby Youth Detention Centre in New South Wales. The terms of this review were to investigate the policy and procedures that were to be put in place as youth were moved from Don Dale into the Berrimah adult prison.

Although the terms of this review were narrower than those of the children's commissioner (who focused on youth justice more broadly and not just youth detention), the Vita review noted serious deficiencies in a number of key areas, including strategic direction, staff training, infrastructure, leadership and resourcing. A youth detention worker was quoted in the report as saying: 'It's hard to be strategic when operating in a climate of daily crisis' (Vita 2015). Vita's report highlighted the lack of staff training, with Northern Territory workers only receiving four days of training compared to 11 weeks for New South Wales prison officers and 30 weeks for New South Wales youth detention officers. The procedures manual and standard operating procedures guiding actions were found to be outdated and inadequate and needed to be 'urgently addressed'. Vita also found 'isolated cases' in which staff had used inappropriate force and/or intimidated detainees. He provided an example of an incident in August 2014 in which 'staff acted inappropriately in threatening a detainee at the Don Dale YDC and attempted to cover up the CCTV surveillance to hide this' (Vita 2015, 50). Finally, he commented on the lack of individualised case management plans and the need for offence-focused programs to be run in rehabilitation. Vita's report included 16 recommendations and emphasised the need for staff training in areas of case management, mediation and negotiation, use of force, youth behaviour, symptoms of foetal alcohol, ADHD and mental health, prosocial modelling, emergency management and cultural awareness (Vita 2015, 18).

Both Bath and Gwyne's and Vita's reports highlighted deficiencies in the training and poor practices around crisis intervention. The children's commissioner's report noted that, in April 2012, surveillance tapes depicting inappropriate and unsafe use of restraint were shown to senior staff of the Department of Justice, which incorporated Correctional Services (DOJ), and that undertakings were provided that such practices would cease. In December 2012, as noted in their report, the Office of the Children's Commissioner sent DOJ a formal recommendation regarding the review and suggested the implementation of safe intervention techniques. It appears that the 2012 recommendations were not implemented at that time or in the subsequent 18 months. 


\section{Appendix}

\section{Timeline of events at Don Dale Youth Detention Centre, 2014-15}

\section{4}

2 August: Two teenagers break out from Darwin's Don Dale Youth Detention Centre. They are on the run for almost four days. The breakout prompts the Northern Territory Government to speed up previously announced plans to move youth detainees to Berrimah Prison.

21 August: Tear gas is used on six young people, one being 14 years old, in response to a disturbance. Leading up to this incident, all six had been held in conditions amounting to solitary confinement for six to 17 days. One young person had left his cell after his cell door was left open by a youth detention officer. The other five young people were locked in their cells. All were tear gassed.

23 August: One detainee escapes his (unlocked) cell. He causes damage to windows and light fittings. Tear gas is used on this detainee and four others who were still in their cells. The five are moved to the new prison at Holtze (before adults were transferred there) as a stopgap measure.

3 September: Children's Commissioner Howard Bath announces an investigation into the tear gas incident and the response by staff. Dr Bath explained that the investigation would consider 'the management, the procedures, what were the circumstances, context of this event occurring'.

14 September: Two teenagers escape from their cells at the new prison at Holtze. They are found sitting on the roof of the prison. The two are moved to maximum security.

15 September: A teenager kicks in a security screen at a new maximum security cell in the AU $\$ 500$ million new prison and escapes into an adjoining courtyard. Three teenagers allegedly overpower security guards at around $9.00 \mathrm{pm}$ and steal a security swipe card at the new prison. They are found on the roof. The teenagers are moved to maximum security.

2 October: The Northern Territory Government commissions a review into youth detention by Michael Vita, Superintendent of Reiby Youth Detention Centre, New South Wales.

29 December: All youth detainees are moved to the old Berrimah prison, which was partially renovated and re-opened as the new Don Dale Youth Detention Centre. 


\section{5}

5 January: Detainees in G Block of Berrimah (not renovated) smash windows, doors and set fire to a mattress. One youth gets on the roof.

February: Vita Review handed down, cataloguing systemic deficiencies in Northern Territory youth detention.

24 February: Three youths attempt to escape by taking a tradesman's car and ramming it into a fence. One escapes over the razor wire and is quickly recaptured.

April: Two boys escape from separate correctional services vans transporting them to Berrimah.

31 May: Several youths in B Block alleged to have caused damage, and two youths escape from Berrimah. The corrections commissioner says the latest escapes are an 'embarrassment' that will not be tolerated, and announces that a new, more secure, maximum security section of Berrimah (B Block) will have anti-climb fences installed. He also says that adult prison guards will be used at Berrimah. Maximum security youths moved to C Block. The two youths who escaped return two days later by driving through the front roller door and are moved to the adult prison.

1 June: Another youth escapes from C Block at Berrimah.

12 June: Northern Territory Corrections bring an application for the two boys who had been held in adult prison for 10 days to have their imprisonment extended while renovations are completed at B Block as the only alternative place to house them, C Block, is 'not an appropriate environment'. The presence of asbestos in C Block, rust in doors, damage and other structural weaknesses in cell doors and internal and external security doors, as well as a lack of trained staff, are provided as reasons.

\section{References}

Allen, G. 2011. Early Intervention: The Next Step. An Independent Report To Her Majesty's Government. London, UK: The Early Intervention Review Team.

Amnesty International. 2014. 'Answers Urgently Needed about the Teargassing of Children in Darwin'. Amnesty International, 2 September. Accessed 8 June 2021, www.amnesty.org.au/teargassing-of-children-in-darwin/.

Anthony, T. 2013. Indigenous People, Crime and Punishment. Abingdon: Routledge. doi.org/10.4324/9780203640296. 
Bath, H. and C. Gwynne. 2015. Own Initiative Investigation Report: Services Provided by the Department of Correctional Services at the Don Dale Youth Detention Centre. NT: Office of the Children's Commissioner. Accessed 8 June 2021, occ.nt.gov. au/_data/assets/pdf_file/0003/440832/pdf-final-investigation-report.pdf.

Blagg, H. and T. Anthony. 2019. Decolonizing Criminology: Imagining Justice in a Postcolonial World. London: Palgrave McMillan. doi.org/10.1057/978-1137-53247-3.

Blagg, H., T. Tulich and Z. Bush. 2017. 'Indefinite Detention Meets Colonial Dispossession: Indigenous Youth with Foetal Alcohol Spectrum Disorders in a White Settler Justice System'. Social and Legal Studies 26 (3): 333-58. doi.org/10.1177/0964663916676650.

Bourgois, P. 2003. In Search of Respect, Selling Crack in El Barrio. New York: Cambridge University Press. doi.org/10.1017/CBO9780511808562.

Commonwealth of Australia. 2017. Royal Commission and Board of Inquiry into the Protection and Detention of Children in the Northern Territory, Findings and Recommendations. Canberra: Commonwealth of Australia.

Dodge, K. A., J. E. Bates and G. S. Pettit. 1990. 'Mechanisms in the Cycle of Violence'. Science, 21 December: 1678-83. doi.org/10.1126/science.2270481.

Howerton, A., R. Burnett, R. Byng and J. Campbell. 2009. 'The Consolation of Going Back to Prison: What 'Revolving Door' Prisoners Think of Their Prospects'. Journal of Offender Rehabilitation 48: 439-61. doi.org/10.1080/ 10509670902979710 .

Lisak, D. and S. Beszterczeys. 2007. 'The Cycle of Violence: The Life Histories of 43 Death Row Inmates'. Psychology of Men and Masculinity 8 (2): 118-28. doi.org/10.1037/1524-9220.8.2.118.

Nossar, V. 2014. 'The Role of the Earliest Years of Life in Future Health and Development_-Delivering Effective Prevention'. 6 March. amaqhealthvision. com (site discontinued).

Royal Commission into Protection and Detention of Children in the Northern Territory. 2017. Volume 1, Chapter 18, Territory Families Recommendation. 18.1: 468 .

Rudd. P. 2015. 'State of Imprisonment: If Locking 'Em up is the Goal, NT's a Success'. The Conversation, 20 April. Accessed 8 June 2021, theconversation.com/state-of-imprisonment-if-locking-em-up-is-the-goalnts-a-success-39185.

Smee, B. 2016. 'The Face of Youth Crime'. NT News. 26 July. 
Spencer, N. 2003. 'Social, Economic and Political Determinants of Child Health'. Pediatrics 112: 704.

Tuari, J. 2013. 'Crime Control, Politics and Policy Production: Critical Reflections on the Demonization of Indigenous Youth'. Paper presented to Australasian Youth Justice Conference, Canberra, 20-22 May.

Vita, M. 2015. Review of the Northern Territory Youth Detention System Report. NSW Juvenile Justice, NSW.

White, R. and C. Cunneen. 2015. 'Social Class, Youth Crime and Youth Justice'. In Youth, Crime and Justice, 2nd ed., edited by B. Goldson and J. Muncie, 17-36. London: Sage. 
This text is taken from Indigenous Australian Youth Futures: Living the Social Determinants of Health, edited by Kate Senior, Richard Chenhall and Victoria Burbank, published 2021 by ANU Press, The Australian National University, Canberra, Australia.

doi.org/10.22459/IAYF.2021.09 